\title{
The Service Excellent for Sharia Banking During Covid-19 Pandemic
}

\author{
Muhammad Wahyuddin Abdullah ${ }^{1}$, Trimulato $^{1, *}$, and St. Hafsah Umar ${ }^{1}$ \\ ${ }^{1}$ Universitas Islam Negeri Alauddin Makassar, Indonesia \\ *Corresponding author. Email: tri.mulato@uin-alauddin.ac.id
}

\begin{abstract}
The development of sharia banking currently continues to experience excellent growth, this can be seen from the increasing share of the sharia banking market which has exceeded 6 percent. In terms of assets, it has reached 500 trillion. In the future, sharia banking will increasingly grow, people are increasingly interested in using sharia banking services and the role of sharia banking in the economy for the country is increasingly showing its contribution. It's just that in conditions due to the during COVID-19 pandemic, the growth of sharia banking is slowing down. Since the emergence of this pandemic in March 2020, it has had an impact on sharia banking. The purpose of this study is to determine the development of sharia banking during the Covid-19 outbreak and to determine the service excellent patterns of sharia during the Covid-19 outbreak. This research is library research, derived from several sources obtained by researchers. The nature of the research used is qualitative, which describes the object of research. The data source used in this study is secondary data from previously presented data from several sources. The analysis technique used in this research is descriptive qualitative by describing the development of sharia banking and its prime services in the conditions of the Covid-19 virus outbreak. The results of this study indicate the development of sharia banking from March 2020 to July 2020. Sharia banking assets grew by 1.16 percent, financing grew by 1.87 percent, and placements with other banks decreased by -7.14 percent. Service excellent patterns that can be done improve digital services, provide relief for financing customers following regulations Financial Services Authority (OJK), to increase the volume of financing with a profit-sharing scheme, further provide assistance and training for affected customers, and provide attractive promotions, to increase third party funds.
\end{abstract}

Keywords: Service Excellent, Sharia Banking, and Covid-19 Pandemic

\section{INTRODUCTION}

The first sharia banking in Indonesia was founded in 1992. This bank was established based on the needs of the Indonesian people, the majority of whose population is Muslim, to have a bank that is free of usury (interest). Sharia banking as intermediary institutions were not known at the time of the Prophet and his companions. However, investment cooperation activities in trading (buying and selling) and other transactions have been carried out individually by market participants who must follow sharia rules. theoretically, the purpose of the existence of a sharia banking is to facilitate the flow of investment from parties that have an excess to be channeled to parties who need funds and ultimately facilitate the circulation of economic resources. Thus, it will smoothen the flow of the economy, to accelerate real sector activities, to be able to grow the economy. Sharia banking industry services to customers are equipped with a variety of financial instruments that are expected to meet the needs of financial transactions that comply with sharia principles. Besides being able to be economically profitable, it can also not violate sharia principles, so it's not just material. Of course, the sharia financial instruments offered must be able to cover various layers of society and industry, including transaction needs for the consumption sector. Likewise, with productive products. In general, Islamic financial products can be divided into two main groups, namely; basic sharia financial products used in traditional banking activities and development products. Products that need to be designed can meet people's needs but are also in line with sharia principles. The basic Islamic financial products are used by Islamic banking institutions in carrying out their 
basic activities as an intermediary institution that functions to transform the liquid assets of the public into various long-term investments. However, in line with the development of activities that occur, Islamic banking products need to develop a variety of financial products to flexibly facilitate transactions in different currencies and hedging instruments. As well as many more sharia banking products that will meet the needs of society, innovation is needed [1].

The development of sharia banking in Indonesia began with the establishment of the Bank Muamalat, which became a pioneer for sharia banking implementing the Sharia Banking system amid the growth and development of conventional banking. The monetary crisis that occurred in 1998 had caused the downfall of conventional banks and the liquidation of many conventional banks. Meanwhile, banks that apply the sharia system continue to exist, are increasingly in demand, have a wider reach, and are strong enough to be strong enough to face the share of crisis. This incident did not just happen in 1998, during a global financial crisis that hit many countries in the world at the end of 2008, Islamic financial institutions can still prove their strength to have resilience against the crisis. Islamic financial institutions remain stable unaffected and unwavering and contribute to benefits, comfort, facilities, and security for stakeholders, in the form of shareholders, securities holders, borrowers, and depositors of funds in Islamic banks and all transacting parties. in Islamic banks. Islamic banking can prove and make every moment of this moment to show that Islamic banking is strong, has added value, is truly able to survive and is immune to the crisis that occurs, and can grow and develop significantly in society. Therefore, it takes a lot of effort and concrete and strategic steps to make it happen and create superior Islamic banking [2].

The blueprint for the development of sharia banking in Indonesia contains the vision, mission, and objectives for the development of sharia banking as well as a set of strategic initiatives with clear priorities to address major challenges and achieve goals within 10 years. That is; achieving a significant share of the sharia banking market through deepening the role of sharia banking in national, regional, and international financial activities in conditions of starting to form integration with other sharia financial sectors. In 2008 the Indonesian government has enacted law number 21 of 2008 concerning sharia banking. Article 2 of the law states that in conducting its business activities, sharia banking is based on sharia principles, economic democracy, and prudential principles. Then article 3 states that Islamic banking aims to support the implementation of national development to improve justice, togetherness, and equitable distribution of people's welfare. Through the law, it is hoped that the development of sharia in Indonesia will be faster and better. This development includes the quality of service and, more importantly, concerns increasing adherence to sharia principles [3].

Sharia banking institutions in Indonesia are currently starting to do a lot of services which include activities to raise funds (funding), channel funds (lending), and other bank services professionally and sustainably so that they can generate maximum profits. The point is whether the Islamic banking institution in managing bank services covering various activities has been based on Islamic law (Al-Qur'an Sunnah and Ijtihad) with the principle of partnership and the principle of profit and loss sharing, not based on interest (usury). As stated in law number 10 of 1998, a commercial bank is a bank that carries out business activities conventionally and/or based on sharia principles which in its activities provide services in payment matters. The activities that can be carried out by commercial banks are raising funds, channeling funds, and other activities. Rural Bank (is a bank that carries out business activities conventionally and / or based on sharia principles (Law Number 21 of 2008) using the term Islamic Rural Bank (BPRS) which in its activities does not provide services in payment matters. The activities that can be carried out are collecting funds and channeling funds. There are two forms of bank operating patterns, namely conventional patterns (interest) and patterns based on sharia principles (profit sharing in profit and loss). Sharia banking as well as conventional banks, according to Kamal Khir, Lokesh Gupta and Bala Shanmugam, is a for-profit financial institution but is prohibited from doing business with usury and engaging in trading that is not following sharia principles [4].

Sharia bankinng never lend money but sell goods to customers by providing facilities to repay the price of goods. Sharia banking lease goods to customers for a certain period. To obtain goods that are sold or leased to the customer, Islamic banks buy from suppliers of goods. Strictly speaking, customers have never obtained funds in the form of loans from sharia banking. The crame act of such a sharia banking is because it are not allowed to charge interest to customers. This means that due to the enactment of the prohibition on lending money at interest, sharia banking do not provide funds directly to customers like conventional banking, but through other crame act [5].

Financing contracts offer avenues for creating and expanding financing, facilitating the financing of transactional contracts, and providing channels for capital formation and resource mobilization between investors and entrepreneurs. The main characteristic of a financing contract is the absence of a debt contract. Financing contracts are intended for financing transactional contracts in the form of trade finance or asset-backed securities or providing capital through equity partnerships which can be realized in several forms such as partnerships ownership or other partnership [6]. 
In these conditions, sharia banking must be able to survive and improve its performance, so that people can still make sharia banking an institution that can survive the Covid-19 outbreak, even though it is affected. The pattern of services provided by Islamic banks during this outbreak is different in usual conditions. There needs to be maximum service excellent to increase customer trust during the COVID-19 outbreak. Service excellent can be the key so that customers remain and the number of customers can increase. Service excellent is needed to maintain the relationship between sharia banking and their customers, both third party fund customers and affected financing customers. For financing customers, sharia banking must follow the rules of the Financial Services Authority (OJK), to provide relief in payment of obligations, due to the impact of the Covid-19. Servive excellent in sharia banking different services during the covid-19 pandemic. Maximizing technology-based services needs to be improved and the intensity of communication with customers must be better. Service excellent service as done in current conditions, and different when it is not in Covid-19 conditions. Service excellent to maintain the level of customer loyalty and improve the performance of sharia banking. In the current development process, sharia banking are also affected by the current COVID-19 outbreak. Many customers of sharia banking experience difficulties in making payment of financing obligations, this is due to these customers due to the impact of business being sluggish due to Covid-19. People use funds a lot as long as they stay at home. Several regulations to prevent this virus outbreak have affected the performance of sharia banking.

Sharia banking faces several challenges amid the Covid-19 outbreak. A Sharia Economics Observer who is also the founder of Karim Consulting, Adiwarman Karim, said that industrial conditions could deteriorate earlier than the conventional banking industry. "Islamic banks can be hit earlier than conventional ones," he said in the Asbisindo and Muamalat Institute Online National Seminar. Pandemic conditions can reduce the competitiveness of sharia banking and people transfer their funds to conventional banking. In general, the challenges in sharia banking during the Covid-19 pandemic were liquidity, and the ratio of non-performing financing (NPF). Adiwarman predicts that Islamic banks will begin to be depressed in July 2020 and August at their peak. In that month, sharia banking lose income from financing, profit sharing, because the customer enters the fourth and fifth months of default. "With decreasing income, there is less competitiveness, the profit-sharing of deposits decreases, it is smaller, so conventional banks are more attractive," he said [7].

The Chair of the Indonesian Sharia Banking Association (Asbisindo) Toni EB Subari said sharia banking tend to bear less risk during the Covid-19 pandemic when compared to conventional bank conditions. This, said Toni, is because the basic concept of sharia banking applies the concept of profit-sharing so that it can naturally mitigate the impact of the Covid-19 pandemic. "The risk of macro conditions is naturally selfmotivated by the concept of sharia business, consciously not aware, because the basic concept of sharia, first of all, is that the business must be fair, balanced, sociable, and secondly, a fair concept due to profit sharing," he said. Toni explained several sharia banking products are not sensitive to pricing so that they are not affected, for example, deposits with a wadiah contract or without interest. The trend of this type of savings is said to have increased significantly every year, such as in Bank Syariah Mandiri, wadiah contract deposits increased by an average of $15 \%-20 \%$ every year. Also, savings with a mudharabah agreement, namely savings with a profitsharing concept. This type of deposit is considered less burdensome when the bank's income also decreases. According to him, the impact of the Covid-19 pandemic which caused an economic slowdown, as well as the financial sector, will only be felt in the second quarter of this year [8].

The Coronavirus pandemic or Covid-19 has continued to hit the Indonesian economy since March 2020. It is felt throughout the industry, its impact is now affecting sharia banking. Minister of Finance Sri Mulyani revealed that sharia banking will experience pressure. This is because there is an increasing credit risk which makes the condition of sharia banking depressed. The impact of this pandemic is felt in sharia banking in Indonesia. Currently, sharia banking is revising its growth target. Because there is an increase in the risk of Islamic institutions due to the pandemic and economic activity and an increased risk of the ability of Islamic institutions to be suppressed, "said Sri Mulyani. She continued, the Covid-19 pandemic has created tremendous shocks in many countries. It is a challenge for the government not to be depressed again. He added that sharia financial institutions must be able to rise. As for sharia financial institutions continue to improve themselves and increase their role in improving people's welfare. "Sharia product strategy sharing must be improved," she explained [9].

In these conditions, sharia banking must be able to survive and improve its performance, so that people can still make sharia banking an institution that can survive the Covid-19 outbreak, even though it is affected. The pattern of services provided by Islamic banks during this outbreak is different in usual conditions. There needs to be maximum service excellence to increase customer trust during the COVID-19 outbreak. Service excellent can be the key so that customers remain and the number of customers can increase. Service excellent is needed to maintain the relationship between sharia banking and their customers, both third party fund customers and affected financing customers. For financing customers, sharia banking must follow the rules of the Financial 
Services Authority (OJK), to provide relief in payment of obligations, due to the impact of the Covid-19 outbreak.

To reduce the impact of COVID-19 on banking activities, including sharia banking, the Financial Services Authority (OJK) has issued several regulations. POJK No. 18 / POJK.03 / 2020 Concerning Written Orders for Handling Bank Problems The POJK mandates the OJK to take the necessary steps to maintain financial system stability, especially in the banking sector amidst the threat of economic downturn as a result of the spread of the COVID-19 virus pandemic. This POJK generally consists of 5 The scope of the regulation applies to Banks, namely Conventional Commercial Banks (BUK), Sharia Commercial Banks (BUS), Rural Banks (BPR), Sharia Rural Banks (BPRS), and branch offices of banks domiciled abroad. Written orders are given to Banks that meet the criteria based on OJK assessment. The authority of the OJK to give written orders to banks to carry out a merger, consolidation, acquisition, and/or integration; and/or Accept merger, consolidation, acquisition, and/or integration. Obligations to a Bank that is given a Written Order to prepare an action plan, as well as implement and maintain the smooth process of merger, consolidation, acquisition, and/or integration following the action plan.[10]

POJK No.11 / POJK.03 / 2020 (POJK Stimulus Covid-19)

1. Credit/financing restructured following POJK Covid-19 Stimulus is reported in the Financial Information Service System (SLIK) with the column Characteristics of Credit or Financing filled with " $1=$ Restructured Credit or Financing" and the Remarks column with "Covid-19".

2. Treatment of Credit / Restructuring Financing following POJK Stimulus is exempted from the calculation of low-quality assets or Loan at Risk (LAR) in assessing the soundness of a bank.

3. Governance Approval of Credit / Restructuring Financing following POJK Covid-19 Stimulus. To speed up the restructuring credit approval process which refers to the Covid-19 stimulus POJK and to avoid buildup if the approval mechanism must be carried out by a higher-ranking official, banks can approve credit restructuring with several governance alternatives while still observing the principles of objectivity, independence, avoiding collisions. interests, and reasonableness.

From the description above, the researchers are interested in conducting deeper research related to sharia banking during the Covid-19 outbreak. Particularly related to the service excellent sharia banking need to do during this outbreak. The purpose of this study is to determine the development of Islamic banking during the
Covid-19 outbreak, from March 2020 to July 2020. As well as to find out the excellent service patterns that Islamic banking needs to do during the Covid-19 outbreak.

Before conducting research related to excellent service at Islamic banks during the COVID outbreak, researchers conducted a literature review of several previous studies that were considered relevant to the research theme. Particularly related to service excellence for sharia banking. As for some of the research referred to as follows.

Mardhiyaturrositaningsih and Muhammad Syarqim Mahfudz in their research entitled The Impact of the Covid-19 Pandemic on the Management of the Sharia Banking Industry: Comparative Analysis. Mentioning that the impact of the Covid-19 Pandemic on the banking intermediation function, based on the results of a comparative study on Bank Syariah Mandiri, Bank Mega Syariah, Bank Syariah Bukopin, Bank Victoria Syariah, and BJB Syariah show that the Bank's intermediation function, namely Financing and Third Party Funds, all banks show turmoil. On the financing side, Bank Syariah Mandiri and Bank Mega Syariah from January to March 2020 tend to increase. Meanwhile, Bank Bukopin Syariah, Victoria Bank Syariah, and Bank BJB Syariah showed fluctuation. On the side of the collection of funds (DPK), Bank Syariah Bukopin showed a decline from January to March 2020. Meanwhile, Bank Mandiri Syariah, Bank Mega Syariah, Bank Syariah BJB, and Bank Victoria Syariah showed fluctuation [11].

Muhammad Ubaidillah and Rizqon Halal Syah Aji in their paper entitled Review of the Implementation of the Extension of the Angsusran Period for Financing in Islamic Banks in the Covid-19 Pandemic Situation, stated that the Al-Baqarah verse 280 Al-Quran has provided financial solutions to creditors to provide concessions to debtors affected by COVID -19. This paragraph has been translated into formal regulations in Indonesia, namely Law Number 2 of 2020 and POJK Number 11 / POJK.03 / 2020. These two regulations are the legal basis for banks to provide credit restructuring or financing to debtors affected by the Covid-19 pandemic. Credit or financing restructuring needs to be provided so that the level of public consumption is maintained and does not experience a major decline. When the level of consumption can be maintained, then economic growth can also be maintained at an optimal level. However, these regulations are not sufficient if implementation in the field is not following what has been declared. Therefore, the Government must be present in-person to monitor the implementation of the regulations it has made [12].

Azwar Iskandar, et in their paper entitled The Role of Islamic Social Economics and Finance during the Covid19 Pandemic stated that as a country with the largest 
Muslim population in the world, Muslims can provide their best role through various forms or models of philanthropy in Sharia Economics and Finance, especially in during the Covid-19 pandemic. This role is expected to be able to overcome the economic shocks that occur and the entire community, especially Muslims, can participate in contributing to recovering these shocks. Among the solutions that can be offered within the framework of the concept and system of Islamic Social Economics and Finance are: (1) by distributing direct cash assistance originating from zakat, infaq, and alms; (2) by strengthening waqf in the form of cash waqf, productive waqf, waqf linked Sukuk and waqf for infrastructure; (3) through superior business capital assistance for the business sector or Micro, Small and Medium Enterprises (SMEs); (4) through the qardhul Hasan scheme; (5) increasing Islamic economic and financial literacy; (6) through the development of Islamic financial technology. If the aforementioned programs, especially direct cash assistance, zakat, infaq, waqf, or CSR, can be promoted, it is hoped that this will help the economic surplus be re-established so that the acceleration of economic recovery can be realized [13].

M. Zainul Wathani and Afiati Kurniasih in their research entitled Excellent Sharia Banking Service Concept Based on the Qur'an The Concept of Islamic Banking Excellent Service By The Qur'an states that the concept of service excellence applied in Islamic banking today has a very close relationship. with the concept of service excellence in the Qur'an. In providing services, Islamic banking has implemented many values contained in the Qur'an such as being gentle with customers, ensuring the halalness of products sold, forgiving customers, and so on. However, in providing services several things need to be considered by Islamic banking, namely sharia banking must not differentiate between prime customers and ordinary customers, and sharia banking must give sincere intentions because of Allah because services that seem good will not be considered righteous deeds if not sincerely intended to Allah SWT. Sharia banking has implemented many values of the service excellence concept contained in the Al-Qur'an, this is due to the many similarities between the current Islamic banking service excellence concept and the service excellence concept contained in the Al-Qur'an. The implementation of the excellent service concept of the Al-Qur'an in Islamic banking services, for example, praying together before starting work, trying to ensure the halalness of the product being sold, there is an SOP that prohibits touching hands with non-mahram customers, and so on [14].

\subsection{Service Excellent}

Service is defined as an act or action of a person or organization to provide satisfaction to customers or fellow employees. Customer means not only customers or customers who buy company products, but also customers within the company (employees and leaders, namely serving fellow employees or leaders who provide services to each other. Thus the type of service can be divided into two groups, namely, the first group of services within the company, which means service between employees and leaders, or among employees [15].

In-service activities, the term service excellent is known, which means caring for customers by providing the best service to facilitate the fulfilment of needs, to achieve guest or customer satisfaction. The purpose of excellent service is to provide services that can meet and satisfy customers or society and provide a focus on service to customers. To be able to provide excellent service and establish good relationships with customers, the key to success is people, because services can establish relationships with customers which are interactions between workers, companies, and communities outside the company. The development of service excellent is part of the company's efforts to provide provision to services in anticipating the demands of professional service needs. Service excellent gives the first impression to the end in serving guests. With this system, it can be used by all parties in making a decision and facilitating the operational activities of a company [16].

Services provided with a focus on user satisfaction are often referred to as excellent service or service excellence. The essence of excellent service is an effort to provide the best service for customers that is oriented towards the interests of the customer/user to enable us to be able to provide optimal satisfaction. Efforts to provide the best service can be realized if we can show good and coordinated abilities, attitudes, appearance, attention, actions, and responsibilities. Service excellent is two words derived from the English language service and excellent. Service means service, duty, and excellence means superior, outstanding, excellent, thus in this perspective, perfect service is one of the important selling points for a service industry. A service is said to be perfect if the impact on consumers is very high loyalty. So that consumers will no longer hesitate to buy products produced by these companies. Loyal customers will automatically market the products or services offered by the company to other consumers voluntarily because they are very comfortable and profitable with this perfect service [17].

\subsection{Sharia Banking}

Sharia banking according to law number 21 of 2008 are Sharia Banking are Bank that carry out their business activities based on Sharia Principles and by type consist of Sharia Commercial Banking and Sharia Rural Bank. Sharia principles are principles of Islamic law in banking 
activities based on fatwas issued by institutions that have the authority to determine fatwas in the field of sharia.

Sharia banking are banks that carry out all business operations based on sharia principles, namely the rules of agreements based on Islamic law between bank and other parties for depositing funds and/or financing business activities, or other activities declared following sharia. In running its business, the sharia banking uses a profitsharing pattern which is the main basis in all its operations, both in products of raising funds, financing, and in other products. Sharia banking products have similarities but are not the same as conventional bank products because of the prohibition of riba, gharar, and maysir. Therefore, products for raising funds and financing at sharia banking must avoid these prohibited elements [18].

\section{METHOD}

The type of research used in this research is a library research, which is sourced from several sources that are relevant to the research theme. The nature of the research used in this research is qualitative research, which describes the development of sharia during the COVID19 period. As well as describing the prime service form of sharia banking during the Covid-19 pandemic.

The data source used in this research is secondary data, namely data that has been presented from an institution that provides data related to the development of sharia banking, in this case, the data issued by the Financial Services Authority (OJK). As well as other sources that are considered relevant to the research theme. The data collection techniques used were through document collection related to the development of sharia banking, and come from good sources from books, journals, and the web of internet. The data analysis technique used in this research is descriptive qualitative, namely the analysis of the object in the study, which is then described by the researcher. In this case, an analysis was carried out related to the development of sharia banking during the Covid-19 outbreak. Then about the service patterns excellent that sharia banking need to do to customers during the Covid-19 pandemic.

\section{RESULTS}

\subsection{The Growth of Sharia Banking During Covid-19 Pandemic}

From the data in Table 1, it shows the development of sharia banking during the Covid-19 outbreak. It is known that this outbreak began to affect activities when entering March 2020. It is known that the development of sharia banking since the emergence of the Covid-19 outbreak grew at a very low value, no more than 2 percent in several components.
Table 1. The Growth of Sharia Banking

\begin{tabular}{|c|l|c|c|c|}
\hline No & Components & $\begin{array}{c}\text { March } \\
\mathbf{2 0 2 0}\end{array}$ & $\begin{array}{c}\text { July } \\
\mathbf{2 0 2 0}\end{array}$ & $\begin{array}{c}\text { Growth } \\
\text { \% }\end{array}$ \\
\hline 1 & Asset & $536.605^{*}$ & $542.830^{*}$ & 1,16 \\
\hline 2 & $\begin{array}{l}\text { Third Party } \\
\text { Funds (DPK) }\end{array}$ & $423.569^{*}$ & $427.158^{*}$ & 0,85 \\
\hline 3 & Financing & $373.591^{*}$ & $380.583^{*}$ & 1,87 \\
\hline 4 & $\begin{array}{l}\text { Placements } \\
\text { with Other } \\
\text { Banks }\end{array}$ & $8.699^{*}$ & $8.078^{*}$ & $-7,14$ \\
\hline 5 & $\begin{array}{l}\text { Number of } \\
\text { Sharia } \\
\text { Banking } \\
\text { Offices }\end{array}$ & 2.931 & 2.955 & 0,82 \\
\hline
\end{tabular}

* Billion Rupiah

Source: Financial Services Authority. Statistics of Sharia Banking on July 2020 (Data processed)

The data shows the growth of Islamic banking in the period March 2020 to July 2020, that the largest growth was in the asset component which grew by 1.16 percent. Other components experienced a decline, namely the placement component with other banks which decreased by -7.14 percent. Overall, if it is seen that the impact of Covid-19 has made the growth of Islamic banks slow down. In conditions such as Islamic banks are expected to maintain stability in their performance and maintain relationships with their customers. One of the efforts that can be made by sharia banking in improving their performance is by providing excellent service to their customers, both third party fund customers, and financing customers. As well as efforts to bring in more customers despite the COVID-19 outbreak.

\subsection{Service Excellent for Sharia Banking during Covid-19 Pandemic}

Since the emergence of the coronavirus outbreak in March which has not subsided until now, it has resulted in many bad effects, besides having an impact on health but also having an impact on declining economic activity. Many businesses have experienced a decline in performance due to the impact of the coronavirus, which makes things abnormal. Various regulations were made so that this virus outbreak did not spread further, but instead had an impact on economic activity, without exception banking institutions were affected by this virus outbreak. Sharia banking has also been hit by the virus, which has slowed down the development of sharia banking. Many sharia banking financing customers are affected, resulting in customers having difficulty fulfilling their obligations to pay their financing. The large number of customers who meet their needs during their stay at home has resulted in third-party funds affecting, many customers taking their funds. In these conditions, the excellent service that Islamic banks must 
provide is different from normal conditions. Several excellent service patterns that Islamic banking can do during the Covid-19 outbreak, to maintain performance and relationships with customers.

First, improving digital-based services. The existence of a ban on gathering and the enactment of rules of guarding distance, resulting in a lack of desire for customers to come directly to the bank office. So that the intensity of coming to the bank will decrease. In this condition, sharia banking can provide services in digital form that provide easy access to their customers. So that customers can still fulfill their banking transactions without coming directly to the bank. Digital services during a pandemic are very much needed, this can be seen by the increasing number of people who use technology with the internet to fulfill their needs. Maximum digital services will make it easier for customers to access banking, especially third party customers, will be very helpful both for transactions and for opening new accounts.

Second, the excellent service that can be done is to provide relief for financing customers who are affected by the coronavirus outbreak, which results in decreased income so that it is difficult to fulfill their obligations to sharia banking. This is in line with the Financial Services Authority Regulation (POJK), which requires banks, including sharia banking, to provide relief for their customers who are affected by Covid-19. This needs to be done by sharia banking, so that customers feel that they are not burdened, and become a form of concern for sharia banking to their financing customers.

Third, service excellent that can be provided by sharia banking, namely increasing the volume of financing with a profit-sharing scheme. In conditions like this where business conditions that are not settled due to the Covid19 outbreak, the rate and flow of economic activity is uncertain. To be able to follow the flow, sharia banking can provide financing with a profit-sharing scheme. This will be fairer for financing customers, especially those who have businesses. If the business in its current state is advanced, then the sharia banking will get the maximum profit sharing, if the business being financed experiences a slowdown, the sharia banking will also bear the risk. In the current economic conditions, profit-sharing schemes are more appropriate for customers who wish to finance productive businesses. The status of sharia banking with profit-sharing financing customers is partners, not creditors and debtors. Under current conditions, sharia banking can provide input and directions to financing customers to run their business better. As a partner, sharia banking can supervise and provide advice to financing customers. In the condition of COVID, there is a profitsharing financing scheme that will be considered fairer, both for customers and for sharia banking.
Fourth, service excellent that can be performed by sharia banking during the Covid-19 outbreak, namely providing assistance and training for financing customers affected by this outbreak. If usually sharia banking are only waiting for payments from financing customers, in current conditions customers need special attention from the bank. Business assistance for affected customers, in the form of advice and directions, so that customers can get back up in their business. Sharia banking can provide input for affected customers so that customers feel more cared for, banks should not only ask about their abilities but also participate in paying attention to customers. If necessary, training that can improve or restore the customer's business needs to be done. Training in the form of business development, especially on marketing through technology. Customers can be given training in utilizing technology in business development. Assistance is needed so that sharia banking can maintain good relations with customers.

Fifth, the service excellent that sharia banking can do during the Covid-19 outbreak is an attractive promotion. In the current condition, many customers have withdrawn their funds to meet their needs, so as a result a lot of funds have been discharged, thus affecting the liquidity of sharia banking. So an attractive promotion needs to be carried out by sharia banking, in the form of giving attractive prizes to third party customers who save their funds during the Covid-19 period. Several parties are not affected by this COVID, therefore efforts to get these party's funds into sharia banking, banks need to provide attractive promotions, so that these parties can save their funds in sharia banking.

\section{CONCLUSION}

The development of sharia banking during the Covid19 outbreak has experienced very slow growth. This can be seen from several components, the assets of sharia banking have only grown 1.16 percent, since the emergence of the Covid-19 outbreak in March 2020. The growth of sharia banking in the period March 2020 to July 2020 has grown no more than 2 percent in several components. Financing grew by 1.87 percent, third party funds grew by 0.85 percent, and placements with other banks decreased by -7.14 percent.

Service excellent needs to be done by sharia banking during the Covid-19 outbreak, to maintain relationships with customers and to improve the performance of sharia banking. The prime service that sharia banking can do during this outbreak is to improve digital services, to meet customer transaction needs without having to gather and visit sharia banking offices. Another service excellent in the form of providing relief for financing customers affected by the COVID-19 outbreak, as regulated by the Financial Services Authority. 
Furthermore, service excellent in the form of increasing the volume of financing with a profit-sharing scheme. In uncertain conditions such as the current profit-sharing financing scheme, it is fair for customers and the bank. Then service excellent in the form of mentoring and training, as a form of attention and concern for customers who are affected by the current conditions, sharia banking need assistance and training to improve and recover the businesses of affected customers. As well as excellent service in the form of attractive promotions, carried out to increase the interest of customers who have funds, to save their funds in sharia banking even in conditions of the Covid-19 outbreak.

\section{REFERENCES}

[1] Darsono, etc. Masa Depan Keuangan Syariah Indonesia. Jakarta: Tazkia Publishing kerjasama Bank Indonesia, 2017

[2] Ikatan Bankir Indonesia, Mengelola Bisnis Pembiayaan Bank Syariah. Jakarta: PT. Gramedia Pustaka Utama, 2015

[3] K. Umam, \& S.U. Budi, Perbankan Syariah: Dasardasar dan Dinamika Perkembangannya di Indonesia. Jakarta: PT RajaGrafindo Persada, 2017.

[4] S. Iska, Sistem Perbankan Syariah di Indonesia. Yogyakarta: Fajar Media Press, 2012.

[5] S.S. Remy, Perbankan Syariah Produk-produk dan Aspek-aspek Hukumnya. Jakarta: Kencana. 2014

[6] Muhamad, Manajemen Keuangan Syariah Analisis Fiqih dan Keuangan. Yogyakarta: UPP STIM YKPN, 2014

[7] L. Puspaningtyas, Sejauh Mana Dampak Covid-19 Terhadap Bank Syariah? In Republika, 2020, retrieved from https://www.republika.co.id/berita/q9sq59383/seja uh-mana-dampak-covid-19-terhadap-bank-syariah. Accessed 9th October 2020

[8] M. Elena, Beban Bank Syariah Tak Seberat Bank Konvensional Saat Covid-19. Apa Penyebabnya? In Bisnis.com, 2020, retrieved from https://finansial.bisnis.com/read/20200514/231/124 0912/beban-bank-syariah-tak-seberat-bankkonvensional-saat-covid-19.-apa-penyebabnya. Accessed 10th October 2020.

[9] R. Anggreani, Sri Mulyani Sebut Perbankan Syariah Mulai Sakit karena Corona, in Okezone Finance,
2020, retrieved from https://economy.okezone.com/read/2020/07/23/320 /2250926/sri-mulyani-sebut-perbankan-syariahmulai-sakit-karena-corona. Accessed 11th October 2020 .

[10] https://www.ojk.go.id/id/berita-dankegiatan/siaran-pers/Pages/Siaran-Pers-OJKKeluarkan-Paket-Kebijakan-Lanjutan-StimulusCovid-19-.aspx, Accessed 11th July 2020.

[11] M.R. Ningsih \& M.S. Mahfudz, "Dampak Pandemi Covid-19 Terhadap Manajemen Industri Perbankan Syariah: Analisis Komparatif'. POINT: Jurnal Ekonomi dan Manajemen. 2(1) (2020) 1-10, DOI: https://doi.org/10.46918/point.v2i1.57

[12] M. Ubaidillah \& R.H.S. Aji, "Tinjauan Atas Implementasi Perpanjangan Masa Angsusran Untuk Pembiayaan di Bank Syariah Pada Situasi Pandemi Covid-19'. Islamic Banking: Jurnal Pemikiran Dan Pengembangan Perbankan Syariah, 6(1) (2020) 116. DOI: https://doi.org/10.36908/isbank.v6i1.159.

[13] A. Iskandar, B.T. Possumah, K. Aqbar, "Peran Ekonomi dan Keuangan Sosial Islam Saat Pandemi Covid-19", SALAM; Jurnal Sosial \& Budaya Syari. $7(7) \quad(2020) \quad 625-638, \quad$ DOI: 10.15408/sjsbs.v7i7.15544.

[14] M.Z. Wathani \& A. Kurniasih, "Konsep Service Excellence Perbankan Syariah Berdasarkan AlQur'an". Nisbah: Jurnal Perbankan Syariah, 1(1) (2015), 1-22. DOI: https://doi.org/10.30997/jn.v1i1.245.

[15] Kasmir. Customer Service Excellent Teori dan Prakti. Depok: Rajawali Press, 2018

[16] M. Apriliawati \& R. Suminar, Pelayanan Prima Pada Orang Tua Siswa di Sempoa SIP TC Paramount Summarecon. Sekretari, 2017

[17] Z. Bastiar, "Service Excellent Dalam Rangka Membentuk Loyalitas Pelanggan”, Manajerial. 9(1) (2010) 54-65 DOI: https://doi.org/10.17509/manajerial.v9i1.1211.

[18] Ascarya, Akad dan Produk Bank Syariah. Jakarta: Rajagrafindo. 2007

[19] Law Number 21 tahun 2008. About Sharia Banking.

[20] Otoritas Jasa Keuangan. Statistik Perbankan Syariah, Juli 2020. 